\title{
Structuration of alfalfa genetic diversity using agronomic and morphological characteristics. Relationship with RAPD markers
}

\author{
Maria-Lucia Crochemore**, Christian Huyghe*, Christian Écalle, Bernadette Julier \\ Station d’amélioration des plantes fourragères, Inra, 86600 Lusignan, France
}

(Received 10 October 1997; accepted 25 February 1998)

\begin{abstract}
Morphological and agronomic characteristics were studied on 46 tetraploid populations of Medicago sativa ssp. sativa and ssp. falcata over three growing cycles in a spaced plant experimental design. The genetic diversity was analysed using principal component analysis and clusters were defined on the Euclidean distances. The wild populations of both subspecies were clustered together because of their fall dormancy and their prostrate growth habit. Among the cultivated populations, genetic differentiation in two major clusters corresponding to the Mediterranean types and the Nordic types was found. A population from Turkey showed a behaviour intermediate between the two groups with a vigorous growth in the different seasons and high seed production. The relationship between the Euclidean distance based on the morphological characteristics and the distance on the RAPD markers was analysed on 26 populations with a generalization of the Mantel statistics. It was shown that the relationship was significant for the major groups of variation, i.e. at the subspecies level, the relationship being not significant for the populations within the groups. (@ Inra/Elsevier, Paris.)
\end{abstract}

\section{Medicago sativa $=$ lucerne $/$ morphological characteristics $/$ Euclidean distance $/$ Mantel test}

Résumé - Étude structurelle des caractéristiques morphologiques et agronomiques de la luzerne. L'étude des caractéristiques morphologiques et agronomiques de 46 populations tétraploïdes de luzerne Medicago sativa ssp. sativa et ssp. falcata a été conduite sur trois cycles sur un dispositif en plantes isolées. La diversité génétique a été analysée à l'aide d'analyses en composantes principales et des groupes de ressemblance établis sur la base des distances euclidiennes. Les populations sauvages des deux sous-espèces sont regroupées en raison de leur dormance automnale et de leur port rampant. Parmi les populations cultivées, la différenciation en deux groupes correspond aux types méditerranéens et aux types nordiques. Une population turque présente un comportement intermédiaire en raison d'une forte croissance sur l'ensemble des cycles et de bonnes caractéristiques de production grainière. La relation entre les structurations obtenues à l'aide des distances euclidiennes sur les caractères morphologiques et de la distance basée sur les marqueurs

Communicated by Hervé Thiellement (Versailles)

* Correspondence and reprints

E-mail: huyghe@lusignan.inra.fr

**Present address: Instituto Agronomico do Parana, IAPAR, Londrina, Parana 86001-970, Brazil 
RAPD a été analysée sur 26 populations à l'aide d'une généralisation du test de Mantel. La relation est significative pour les groupes de variation qui correspondent au niveau sous-spécifique mais n'est pas significative pour les populations au sein des groupes. (@ Inra/Elsevier, Paris.)

Medicago sativa $=$ luzerne $/$ morphologie $/$ distance euclidienne /test de Mantel

\section{INTRODUCTION}

More than half of the varieties and cultivated populations of lucerne originate from the crosses between the perennial forms of Medicago sativa ssp. sativa and Medicago sativa ssp. falcata. Because of the cross-pollination and the autotetraploid status of the cultivated forms of this complex of species, a wide genetic diversity has been described among populations from different geographic origins [1, 34, 37]. The tetraploid form of the subspecies sativa is only found in its wild status in some locations of the Iberian Peninsula where the wild populations called 'mielgas' show a prostrate growth habit and rhizomatous root system. Sativa populations are sometimes found on road sides or as weeds in cultivated fields [7, 30]. The true sativa types, without any introgression by falcata are mainly cultivated in Mediterranean areas, in the Middle-East and in India. The falcata populations are mainly spontaneous. The main morphological characteristics of this subspecies used in the genetic improvement of the cultivated populations are its pronounced fall dormancy, the tolerance to drought and to diseases, and its creeping growth habit [26]. In northern areas, spontaneous hybrids between the two subspecies can be found.

The genetic resources presently available are the registered varieties and the wild populations and the landraces in which most of the genetic diversity is found. The erosion of the genetic diversity in most of the cultivated species underlines the need to describe the genetic diversity available in the material under collection which could be stored as genetic resources or used in breeding programs.

The present genetic study aims at describing the diversity available at the tetraploid level in a range of varieties, landraces and wild populations cover- ing the range of geographic diversity under which lucerne is grown with a focus on western Europe. Characteristics describing the plant morphology, the grain and forage production were evaluated in a spaced plant design. The description of the genetic diversity obtained with these characteristics will be compared with the results from the analysis with RAPD markers [5].

\section{MATERIALS AND METHODS}

\subsection{Plant material}

Forty-six populations were studied. A description of their origin is given in table I. These populations were chosen to cover the widest range of geographic origins of tetraploid forms in the Medicago sativa complex. The wild forms were three falcata populations from Ukraine and the east of France, which is considered as the western limit of the natural distribution of spontaneous falca$t a$, and two sativa populations from the north of Spain [29]. The rest of the material showed various levels of introgression between the two subspecies and originated from different regions of Europe, north Africa, America and Asia. The west-European populations were over numerous in order to estimate their diversity compared to the populations from other regions.

The populations were classified into three major groups of diversity, the wild populations, the cultivated Nordic types including the Flemish material and the Mediterranean types (table I).

\subsection{Experimental design}

The trial was planted at the Forage Crops Breeding Station (SAPF, Inra) of Lusignan (France) in a randomized block design, with three replications. Each plot included 30 spaced plants, $70 \mathrm{~cm}$ apart in both direc- 
Table I. Origin of the 46 populations analysed in the study.

\begin{tabular}{|c|c|c|c|c|c|}
\hline Population & Country & Sub-species & Type & Group $^{1}$ & RAPD analysis ${ }^{2}$ \\
\hline Maron & France & falcata & wild & 1 & $\mathrm{x}$ \\
\hline Malzeville & France & falcata & wild & 1 & $\mathrm{x}$ \\
\hline Krasnokutskaya & Ukraine & falcata & wild & 1 & \\
\hline Villa Nueva & Spain & sativa & wild & 3 & \\
\hline Monte Oscuro & Spain & sativa & wild & 3 & $\mathrm{x}$ \\
\hline Dem3 & Morocco & sativa & landrace & 3 & $\mathrm{x}$ \\
\hline Pool5 & Morocco & sativa & pool & 3 & $\mathrm{x}$ \\
\hline Gabes & Tunisia & sativa & landrace & 3 & $\mathrm{x}$ \\
\hline Provence & France & sativa & landrace & 3 & \\
\hline Magali & France & sativa & variety & 3 & $\mathrm{x}$ \\
\hline Medalfa & France & sativa & variety & 3 & \\
\hline Lodi & Italy & sativa & variety & 3 & $\mathrm{x}$ \\
\hline Aragon & Spain & sativa & variety & 3 & \\
\hline Ampurdan & Spain & sativa & variety & 3 & \\
\hline Tierra de Campos & Spain & sativa & variety & 3 & \\
\hline Mediterraneo & Spain & sativa & variety & 3 & $\mathrm{x}$ \\
\hline Totana & Spain & sativa & variety & 3 & \\
\hline Coussouls & France & sativa & variety & 3 & $\mathrm{x}$ \\
\hline Crioula & Brazil & sativa & variety & 3 & \\
\hline WL514 & USA & sativa & variety & 3 & $\mathrm{x}$ \\
\hline CUF101 & USA & sativa & variety & 3 & $\mathrm{x}$ \\
\hline Sewa & Egypt & sativa & landrace & 3 & $\mathrm{x}$ \\
\hline Chypre & Cyprus & sativa & landrace & 3 & \\
\hline Higazi & Sudan & sativa & landrace & 3 & $\mathrm{x}$ \\
\hline 2929 & India & sativa & landrace & 3 & \\
\hline Lamia & Greece & sativa & variety & 3 & \\
\hline Kayserie & Turkey & sativa & variety & 3 & \\
\hline Marais de Luçon & France & sativa & landrace & 2 & $\mathrm{x}$ \\
\hline Flamande & France & sativa & landrace & 2 & $\mathrm{x}$ \\
\hline Natsuwakaba & Japan & sativa & variety & 2 & $\mathrm{x}$ \\
\hline Europe & France & sativa & variety & 2 & $\mathrm{x}$ \\
\hline Rival & France & sativa & variety & 2 & $\mathrm{x}$ \\
\hline Resis & France & sativa & variety & 2 & \\
\hline Maya & France & sativa & variety & 2 & $\mathrm{x}$ \\
\hline Alegro & France & sativa & variety & 2 & \\
\hline Orca & France & sativa & variety & 2 & $\mathrm{x}$ \\
\hline $63-28 \mathrm{P}$ & France & sativa & experimental & 2 & $\mathrm{x}$ \\
\hline Luzelle & France & sativa & variety & 2 & $\mathrm{x}$ \\
\hline $27-48$ & France & sativa & experimental & 2 & \\
\hline Julus & Sweden & sativa & variety & 2 & $\mathrm{x}$ \\
\hline Alfagraze & USA & sativa & variety & 2 & \\
\hline Altfranken-Sm-St & Germany & sativa & variety & 2 & \\
\hline Radouga & Russia & sativa & variety & 2 & \\
\hline Sabre & Canada & sativa & variety & 2 & $\mathrm{x}$ \\
\hline Victory & Canada & sativa & variety & 2 & $\mathrm{x}$ \\
\hline Rhizoma & Canada & sativa & variety & 2 & \\
\hline
\end{tabular}

${ }^{1}$ Group 1: falcata populations, group 2: Nordic-type populations, group 3: Provence and Mediterranean-type populations; ${ }^{2}$ : populations used in the RAPD markers analysis are mentioned [5]. 
tions. The soil was a loamy clay soil with $\mathrm{pH} 6.8$. No inoculation was performed prior to transplanting because of the presence of indigenous Rhizobium meliloti populations. The seeds were mechanically scarified to obtain a homogeneous germination. The seeds were germinated in Petri dishes placed for $48 \mathrm{~h}$ in a growth cabinet at $24{ }^{\circ} \mathrm{C}$. The seedlings were then planted in a glasshouse. After 2 months in the greenhouse, the plants were clipped and transplanted into the field on 18 April 1994.

Plants were studied over four growth cycles, two in the plantation year, two in the next year. During the first cycle, following the transplanting, the flower colour was the only characteristic scored, as the growth was affected by the stress due to transplanting. Plants were cut on 21 July 1994. Cycle 2 (C2) included all the characteristics measured during the summer regrowth. The plots were cut on 26 September 1994. Cycle 3 (C3) included the characteristics measured during the following winter and the spring growth. The plots were cut on 14 June 1995. The summer growth was considered as cycle 4 (C4).

\subsection{Characteristics}

The flower colour was individually scored on the day of flowering. The following scores were used: $1=$ purple flower, 2 = variegated flower with a predominance of purple, 3 = variegated flower with a predominance of yellow, $4=$ yellow flower

The ability to regrow was assessed within the 2 weeks following the cut, either by a score from $1=$ no regrowth to $5=$ vigorous regrowth (REGC2 and REGC4) or by an individual measurement of the plant height (HEC2, HEC4). The individual plant height was also measured 2 weeks after the cut of autumn 1994 (HEAC3). The regrowth during the winter (REGWC3) was scored on 16 December 1994 on a plot basis from $1=$ no regrowth to $5=$ vigorous regrowth. The regrowth in early spring (SREGC3) was estimated in cycle 3 by a visual estimation of the aerial biomass on 31 March 1995 from $1=$ no growth to $5=$ vigorous growth. The plant height was measured on 18 April 1995 (HESC3).

The plant growth habit was scored on a plot basis during the cycles 2 and 3 (GHC2 and GHC3) at the beginning of flowering from $1=$ erect to $5=$ prostrate. At the beginning of cycle 3 , the rhizomatous aspect of the plants (DIAMC3) was evaluated through a measurement of the plant diameter (mean of two perpendicular measurements at the soil surface) as described by Heinrichs [17] and Julier et al. [21].
The date of flowering was scored when $50 \%$ of the plants had one open flower on a plot basis except in cycle 2 when it was scored on average across the replications. The flowering dates were named FLOC2, FLOC3 and FLOC4.

At the date of flowering, for each cycle, the longest stem of each plant was sampled. The length of these stems was measured (SLC2, SLC3 and SLC4). The number of internodes from the bottom to the first inflorescence was counted (NBINTC2, NBINTC3 and NBINTC4) and the number of leafy branches was counted for the cycles 3 and 4 (NBBRC 3 and NBBRC4).

These stems were dried and weighed for each of the cycles (SDMC2, SDMC3 and SDMC4 in g/stem). The leaf to stem ratios for each of the cycles ( $\mathrm{L} / \mathrm{SC} 2, \mathrm{~L} / \mathrm{SC} 3$ and $\mathrm{L} / \mathrm{SC} 4$ ) were predicted using NIRS spectra. The equation of prediction was defined using true values based on samples of ten stems. For the study, 72, 45 and 45 samples were taken from the cycles 2,3 and 4 , respectively.

At the cut of cycle 3 , the dry matter per plot was measured. Taking into account the number of plants per plot, the mean dry matter per plant was calculated (DMPLC3).

At the end of cycle 4, the characteristics related to the seed production were measured. The third inflorescence of the longest stem of each plant was sampled. The number of pods per inflorescence (NBPC4), the number of seeds per inflorescence (NBSC4), the number of seeds per pod (NBSPC4) were counted. The total seed production was measured by combining the whole plots and the mean seed yield per plant was calculated (SYPLC4). The mean seed weight (MSWC4) was measured. The percentage of hard seeds was estimated within 2 weeks after the harvest on two replications of 100 seeds per plot (HARDC4). The seeds were put on an imbibed filter paper in a Petri dish in an oven at $24{ }^{\circ} \mathrm{C}$ for $7 \mathrm{~d}$ [19]. The number of impermeable seeds, i.e. hard seeds, was counted.

When the characteristics were measured on each individual plant, the value for the plot was calculated as the mean of the individual values.

\subsection{Statistical analysis}

Analyses of variance were performed on the plot values for the different characteristics. The effects of population, replication and cycle were tested for the characteristics which were evaluated during the three cycles. 
For the other characteristics, the effects of population and replication were tested.

A principal component analysis was made on the centred and standardized variates using the mean population value across the three replications. In order to illustrate the genetic diversity, the Euclidean distances between populations on the centred and standardized variates were calculated. Cluster analysis was conducted on the Euclidean distance matrix with the unweighted pairgroup method based on arithmetic averages (UPGMA) [32].

These analyses were performed either on all the populations or on the 41 cultivated populations.

The relationship between the Euclidean distance matrix and the distance matrix obtained with RAPD markers [5] was analysed. Twenty-six populations were common to both studies, these populations are indicated in table 1 . The direct comparison between the dendrograms is not fully adequate because the analysis of the correlation coefficients between distance matrices confronted the question of the number of degrees of freedom. Thus, the analysis of the relationship was performed using the approach developed by Mantel [25]. The principle of this approach is to calculate the sum of the cross-product of the distance matrices and to compare this sum with the value expected according to a null hypothesis (no difference between the distance matrices). As three major groups of material (table I) were included in the set of populations of the present study, the test of Mantel was modified to consider a possible effect of the group. Thus, three parameters were defined: $\mathrm{Z}_{\text {total }}$ as described by Mantel, $\mathrm{Z}_{\text {within }}$ for the similarity within groups, sum of the cross-products of the distances when the populations belong to the same group, and $\mathrm{Z}_{\text {between }}$ for the similarity between groups, sum of the cross-products when the populations belong to different groups. $X_{i j}$ and $Y_{i j}$ are the distances between the populations $\mathrm{i}$ and $\mathrm{j}$ for the morphological traits and the RAPD markers, respectively

$$
Z_{\text {toral }}=\sum_{i=1}^{N} \sum_{j=1}^{N} X_{i j} Y_{i j}
$$

The $\mathrm{N}$ populations belong to $\mathrm{I}_{\mathrm{g}}$ groups of size $\mathrm{N}_{\mathrm{g}}$.

$$
Z_{\text {within }}=\sum_{\mathrm{k}=1}^{\mathrm{I}_{\mathrm{g}}} \sum_{\mathrm{i}=1}^{N_{\mathrm{kg}}} \sum_{\mathrm{j}=1}^{N_{\mathrm{kg}}} \mathrm{X}_{\mathrm{ij}} \mathrm{Y}_{\mathrm{ij}}
$$

It can be shown that:

$$
Z_{\text {total }}=Z_{\text {within }}+Z_{\text {between }}
$$

The significance of the $\mathrm{Z}$ values was estimated through comparison with the distribution of each $Z$ value according to a null hypothesis. For the $\mathrm{Z}_{\text {total }}$, the null hypothesis was obtained through random permutations of the lines and columns of one of the matrices. For the $\mathrm{Z}_{\text {within, }}$, the null hypothesis was simulated by random permutations of the populations within each group. For the $\mathrm{Z}_{\text {between }}$, random permutations between groups were performed, the size of the groups being kept constant. For each test, 2000 random permutations were made. The calculated values of the different $\mathrm{Z}$ parameters were compared to the null distribution to estimate a probability of error when rejecting the null hypothesis.

\section{RESULTS}

\subsection{Analysis of variance}

On the characteristics evaluated on the three cycles, i.e. length of stems, number of internodes, dry matter mean of a stem and leaf to stem ratio, the ANOVA showed significant population $\times$ cycle interactions (table II). The analysis of the populations on the basis of their mean across the different cycles would thus not be relevant. For these characteristics, their values at each cycle were then analysed as independent variates.

The analyses of variance with either all the populations or only the cultivated ones on the 35 characteristics showed significant population effect, except for the plant height in spring in cycle 3 (HESC3). The characteristic was then excluded from the later analyses. For most of the characteristics, the effect of the replication was not significant and always less important than the population effect (table III). All the characteristics with a significant population effect were used for the susequent analyses.

\subsection{Principal component analysis on all the populations}

Figure 1.A shows the contribution of the different characteristics to the first two axes of the PCA. These axes represented 41.5 and $21.1 \%$ of the total variation, respectively, while the third axis repre- 
Table II. Analysis of variance on the characteristics common to the three cycles of the study.

\begin{tabular}{lccccc}
\hline Source of variation & d.f. & NBINT & LS & SDM & L/S \\
\hline Cycle & 2 & $4036.24 * * *$ & $3882.72 * * *$ & $2281.46 * * *$ & $569.92 * * *$ \\
Replication & 2 & $0.42 \mathrm{~ns}$ & $5.38^{*}$ & $3.24 *$ & $0.75 \mathrm{~ns}$ \\
Population & 46 & $8.65 * * *$ & $57.29 * * *$ & $33.50^{* * *}$ & $7.00^{* * *}$ \\
Cycle $\times$ Pop. & 46 & $6.87 * * *$ & $18.43 * * *$ & $13.46 * * *$ & $6.91 * * *$ \\
C.V. (\%) & & 8.03 & 4.26 & 12.87 & 11.11 \\
\hline
\end{tabular}

The values correspond to the F of the analysis of variance. The significance is given. NBINT: number of internodes; LS: length of the longest stem; SDM: dry matter mean per stem; L/S: leaf to stem ratio. ns: non-significant; *, ***: significant at $5 \%$ and $1 \%$, respectively.
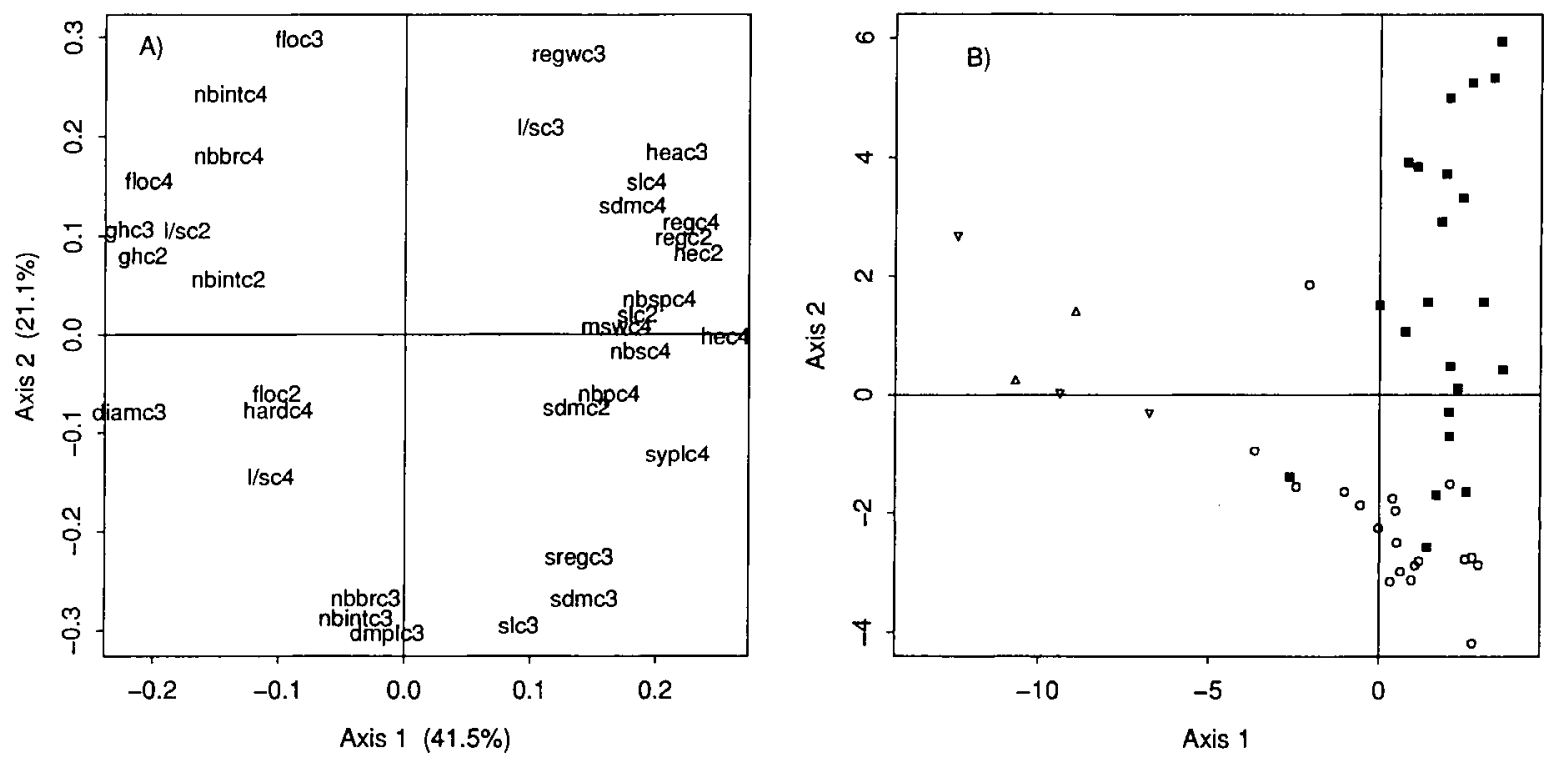

Figure 1. PCA diagrams on the 46 populations. The graph A shows the contribution of the variates to the axis 1 and 2 . The distribution of the populations on the first two axes of the PCA is shown on graph B. Symbols: $\nabla$ : falcata populations; $\triangle$ : wild mielga populations; $\mathbf{n}$ : Mediterranean-type populations; $O$ : Flemish-type populations.

sented $10.7 \%$ of the total variation. The first component was positively correlated to the plant height after the cut in cycle 2 (HEC2) and cycle 4 (HEC4), to the length (SLC2 and SLC4) and the dry matter mean of the stems (SDMC2 and SDMC4) at flowering at the same cycles. The characteristics related to the seed production, i.e. NBPC4, NBSPC4, NBSPL, MSWC4 and SYPLC4 were also positively correlated to the first axis. The growth habit (GHC2 and GHC3), the flowering date during the summer cycles (FLOC2 and FLOC4) and the plant diameter in cycle 3 (DIAMC3) were negatively correlated to the first axis. The second component was positively correlated to the ability to grow during the winter (REGWC3), to the numbers of internodes (NBINTC4) and branches (NBBRC4) in cycle 4 , to the flowering date (FLOC3) and the leaf to stem ratio in cycle 3 (L/SC3). It was negatively correlated to the dry matter mean of the stems (SDMC3) at cycle 3, the stem length (SLC3) and the growth characteristics of this cycle. 
Table III. Analysis of variance on all the characteristics evaluated on the 46 populations or on the 41 cultivated populations.

\begin{tabular}{|c|c|c|c|c|c|}
\hline \multirow[b]{2}{*}{ Cycle } & \multirow[b]{2}{*}{ Character } & \multicolumn{2}{|c|}{46 populations } & \multicolumn{2}{|c|}{41 populations } \\
\hline & & Replication & Population & Replication & Population \\
\hline \multirow{8}{*}{$\mathrm{C} 2$} & REGC2 & $0.11 \mathrm{~ns}$ & $8.58 * * *$ & $0.04 \mathrm{~ns}$ & $2.86 * * *$ \\
\hline & HEC2 & $4.42 *$ & $14.81 * * *$ & $3.43 *$ & $4.98 * * *$ \\
\hline & GHC2 & $1.99 \mathrm{~ns}$ & $17.54 * * *$ & $1.66 \mathrm{~ns}$ & $9.09 * * *$ \\
\hline & FLOC2 & - & - & - & - \\
\hline & SLC2 & $7.07 *$ & $30.43 * * *$ & $7.69 * *$ & $18.99 * * *$ \\
\hline & NBINTC2 & $0.10 \mathrm{~ns}$ & $10.70 * * *$ & $0.08 \mathrm{~ns}$ & $6.92 * * *$ \\
\hline & DMC2 & $10.00 * * *$ & $21.60 * * *$ & $9.86 * * *$ & $15.96 * * *$ \\
\hline & $\mathrm{L} / \mathrm{SC} 2$ & $0.83 \mathrm{~ns}$ & $3.17 * * *$ & $2.03 \mathrm{~ns}$ & $2.56 * *$ \\
\hline \multirow{13}{*}{$\mathrm{C} 3$} & HEAC3 & $4.39 *$ & $99.93 * * *$ & $5.77 *$ & $50.19 * * *$ \\
\hline & REGWC3 & $5.00 *$ & $22.95 * * *$ & $5.18 *$ & $20.08 * * *$ \\
\hline & DIAMC3 & $14.84 * * *$ & $75.08 * * *$ & $17.20 * * *$ & $28.34 * * *$ \\
\hline & SREGC3 & $0.00 \mathrm{~ns}$ & $11.93 * *$ & $0.10 \mathrm{~ns}$ & $8.74 * *$ \\
\hline & HESC3 & $46.98 * * *$ & $0.88 \mathrm{~ns}$ & $43.68 * * *$ & $0.84 \mathrm{~ns}$ \\
\hline & GHC3 & $9.18 * *$ & $14.76 * * *$ & $10.34 * * *$ & $4.59 * * *$ \\
\hline & FLOC3 & $11.59 * * *$ & $17.27 * * *$ & $10.37 * * *$ & $15.81 * * *$ \\
\hline & SLC3 & $1.52 \mathrm{~ns}$ & $18.97 * * *$ & $0.79 \mathrm{~ns}$ & $15.36 * * *$ \\
\hline & NBIN'TC3 & $1.03 \mathrm{~ns}$ & $5.84 * * *$ & $0.92 \mathrm{~ns}$ & $7.39 * * *$ \\
\hline & NBBRC3 & $1.49 \mathrm{~ns}$ & $3.55 * * *$ & $0.64 \mathrm{~ns}$ & $3.97 * * *$ \\
\hline & DMC3 & $1.49 \mathrm{~ns}$ & $19.49 * * *$ & $1.18 \mathrm{~ns}$ & $14.70 * * *$ \\
\hline & DMPLC3 & $3.99^{*}$ & $5.59 * * *$ & $2.60 \mathrm{~ns}$ & $5.66 * * *$ \\
\hline & L/SC3 & $0.43 \mathrm{~ns}$ & $9.78 * * *$ & $1.53 \mathrm{~ns}$ & $10.33 * * *$ \\
\hline \multirow{14}{*}{$\mathrm{C} 4$} & REGC4 & $0.70 \mathrm{~ns}$ & $15.02 * * *$ & $0.28 \mathrm{~ns}$ & $5.98 * * *$ \\
\hline & HEC4 & $7.05 *$ & $133.05 * * *$ & $6.10 *$ & $19.13 * * *$ \\
\hline & FLOC4 & $0.45 \mathrm{~ns}$ & $23.42 * * *$ & $0.49 \mathrm{~ns}$ & $7.09 * * *$ \\
\hline & SLC4 & $2.32 \mathrm{~ns}$ & $88.21 * * *$ & $3.26 *$ & $67.47 * * *$ \\
\hline & NBINTC4 & $1.59 \mathrm{~ns}$ & $8.97 * * *$ & $1.13 \mathrm{~ns}$ & $5.54 * *$ \\
\hline & NBBRC4 & $0.05 \mathrm{~ns}$ & $5.14 * * *$ & $0.20 \mathrm{~ns}$ & $3.23 * * *$ \\
\hline & DMC4 & $0.60 \mathrm{~ns}$ & $26.00 * * *$ & $0.96 \mathrm{~ns}$ & $17.59 * * *$ \\
\hline & $\mathrm{L} / \mathrm{SC} 4$ & $0.65 \mathrm{~ns}$ & $15.38 * * *$ & $0.25 \mathrm{~ns}$ & $13.94 * * *$ \\
\hline & NBPC4 & $3.07 \mathrm{~ns}$ & $3.80 * * *$ & $2.59 \mathrm{~ns}$ & $2.52 * *$ \\
\hline & NBSC4 & $0.97 \mathrm{~ns}$ & $4.06 * * *$ & $0.81 \mathrm{~ns}$ & $2.51 * *$ \\
\hline & NBSPC4 & $0.98 \mathrm{~ns}$ & $3.79 * * *$ & $1.11 \mathrm{~ns}$ & $1.96 *$ \\
\hline & MSWC4 & $8.91 * *$ & $2.84 * * *$ & $8.40 * *$ & $2.15 *$ \\
\hline & SYPLC4 & $5.97 *$ & $10.29 * * *$ & $6.27 *$ & $4.10 * * *$ \\
\hline & HARDC4 & $6.09 *$ & $7.93 * * *$ & $10.87 * * *$ & $9.09 * * *$ \\
\hline
\end{tabular}

The $\mathrm{F}$ values of the ANOVA are given as well as their significance. ns: non-significant; *,**, *** significant at the level $5 \%, 1 \%$ and $1 \%$, respectively.

The distribution of the populations on the graph of these first two axes clearly separated the wild populations from the cultivated ones (figure l.B). The cultivated populations had high values on the first axis because of their strong summer growth and high seed production compared to the wild, to their erect growth habit and to the absence of rhizomatous plants. The cultivated populations were scattered along the second axis. 


\subsection{Principal component analysis on the cultivated populations}

Because of their position, the wild populations may well mask the description of the genetic variation within the cultivated populations. Consequently, a second PCA was performed on the cultivated populations.

The first two axes explained 33.6 and $15.3 \%$ of the total variation, respectively, while the third axis contributed $14 \%$ of the total variation. The first component (figure 2.A) was positively correlated with the regrowth ability after the cut in cycles 2 (REGC2) and 4 (REGC4), the plant height in the cycles 2 (HEC2) and 4 (HEC4), the growth during the winter (REGWC3), the flowering dates in cycles 3 (FLOC3) and 4 (FLOC4), the leaf to stem ratio in cycle $3(\mathrm{~L} / \mathrm{SC} 3)$ and the morphological characteristics measured in cycle 4 . It was negatively correlated with the plant diameter (DIAMC3), the morphological characteristics in cycle 3 and with the leaf to stem ratio in cycle 4 (L/SC4). The construction of this axis was fairly similar to the second axis on the PCA on all the populations.

The second axis was positively correlated with the seed production per inflorescence and per plant (NBSPC4, NBSC4 and SYPLC4) and the dry matter mean per stem in cycle 3 (SDMC3). It was negatively correlated with the growth habit (GHC2 and GHC3) and the leaf to stem ratio in cycle 2 (L/SC2).

The distribution of the cultivated populations on the scatter plot is shown on figure 2.B. The first axis separated the populations which regrew quickly after the cut and with a vigorous winter growth. These populations were less dormant and tended to flower late in cycles 3 and 4. To this group belonged the Mediterranean populations such as the landraces from Spain (Aragon, Ampurdan, Tierra de Campos, Mediterraneo and Totana), from north and eastern Africa (Sewa, Dem3, Pool5, Higazi and Gabes), the Italian variety Lodi, varieties from North America (CUF101 and WL514), from Brazil (Crioula) as well as populations from India (2 929) and Cyprus. The French Provence-type populations (Magali and Provence) also belonged to this group.
The flowering dates in cycles 2 and 4 were positively correlated to the number of internodes below the first inflorescence ( 0.46 and 0.76 in cycles 2 and 4 , respectively) while the correlation was negative in cycle $3(-0.61)$.

The second group characterized by negative values on the axis 1 showed a slower regrowth after the cuts and a more pronounced fall dormancy. It flowered earlier in cycles 3 and 4 . The dry matter per plant in cycle 3 was higher. In this group, there were French Flemish populations, European populations from Sweden (Julus), Germany (AltfrankenSchmidt-Steinbach), Greece (Lamia) and Russia (Radouga), varieties from Canada (Sabre, Victory and Rhizoma), USA (Alfagraze), Japan (Natsuwakaba) and a population from Turkey (Kayserie). This second group will later be called 'Nordic' in the present paper.

\subsection{Dendrogram obtained on all the populations}

In the dendrogram obtained with all the characteristics (figure 3), there is one cluster corresponding to the wild falcata and sativa populations and two clusters corresponding to the two cultivated groups previously described: Mediterranean populations on the top and the Nordic populations on the bottom part of the dendrogram. These two clusters were separated by the Turkish population Kayserie. The intermediate position of this population was due to some mixed characteristics such as its late flowering in cycle 2 (close to the Mediterranean group), the lengthy stems in all three cycles, the heavy mean weight of the stems in cycles 2 and 3 and its high seed yield per plant (close to the Nordic group). In the dendrogram, Crioula which was close to the Mediterranean population on the first two axes of the PCA was clustered with the Nordic populations in the dendrogram.

Table IV shows the proportions of the different flower colours for the 46 populations. The falcata populations were completely different from the rest of the material because of their predominantly yellow flowers. Among the sativa populations, three 

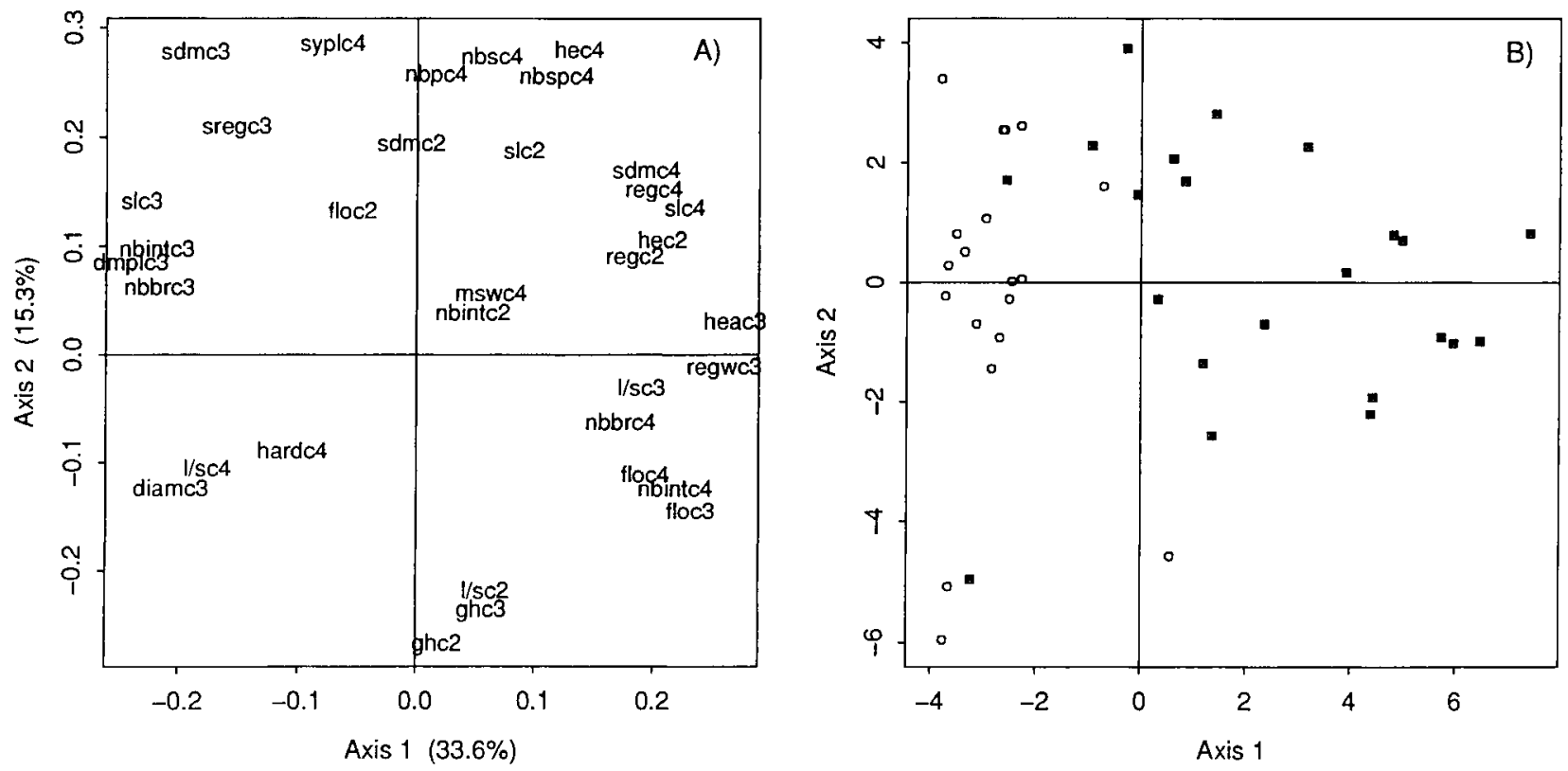

Figure 2. PCA diagrams on the 41 cultivated populations. The graph A shows the contribution of the variates to the axis 1 and 2 . The distribution of the populations on the first two axes of the PCA is shown on graph B. Symbols are as in figure 1 .

groups may be distinguished. The first one with 96-100\% of purple flowers gathered materials which are mainly Mediterranean. The next group, with between 79 and $90 \%$ of purple flowers included mainly Flemish-type material with some landraces from Spain. The third group showed a lot of variegated flowers, the purple flowers accounting for $42-73 \%$ only of the population. These three groups correspond to a gradient of introgression of the sativa origin by falcata populations.

\subsection{Relationship between the Euclidean distance and the distance obtained on RAPD markers}

Figure 4 shows the relationship between the distance based on the agro-morphological characteristics and the distance based on the RAPD markers for the 26 populations common to both studies.

Table IV shows the calculated value of the different $Z$ parameters, the range of variation for the sim- ulated values under the null hypothesis and the probability of error when rejecting the null hypothesis. The global relationship $\left(Z_{\text {total }}\right)$ was shown to be significant. This is due to the fact that the separation between the groups, and especially between the falcata versus the sativa populations was found with the morphological characteristics as well as with the RAPD markers. The $Z_{\text {between }}$ value was shown to be highly significant. In contrast, there was no similarity of the genetic structure within the groups when using the morphological characteristics or the RAPD markers. Indeed, the distribution of the $Z_{\text {within }}$ according to the null hypothesis gave a value higher than the calculated one in $10 \%$ of the random permutations.

\section{DISCUSSION}

The study of the morphological and agronomic characteristics was made in a spaced plant design in which each individual plant was not altered by the 


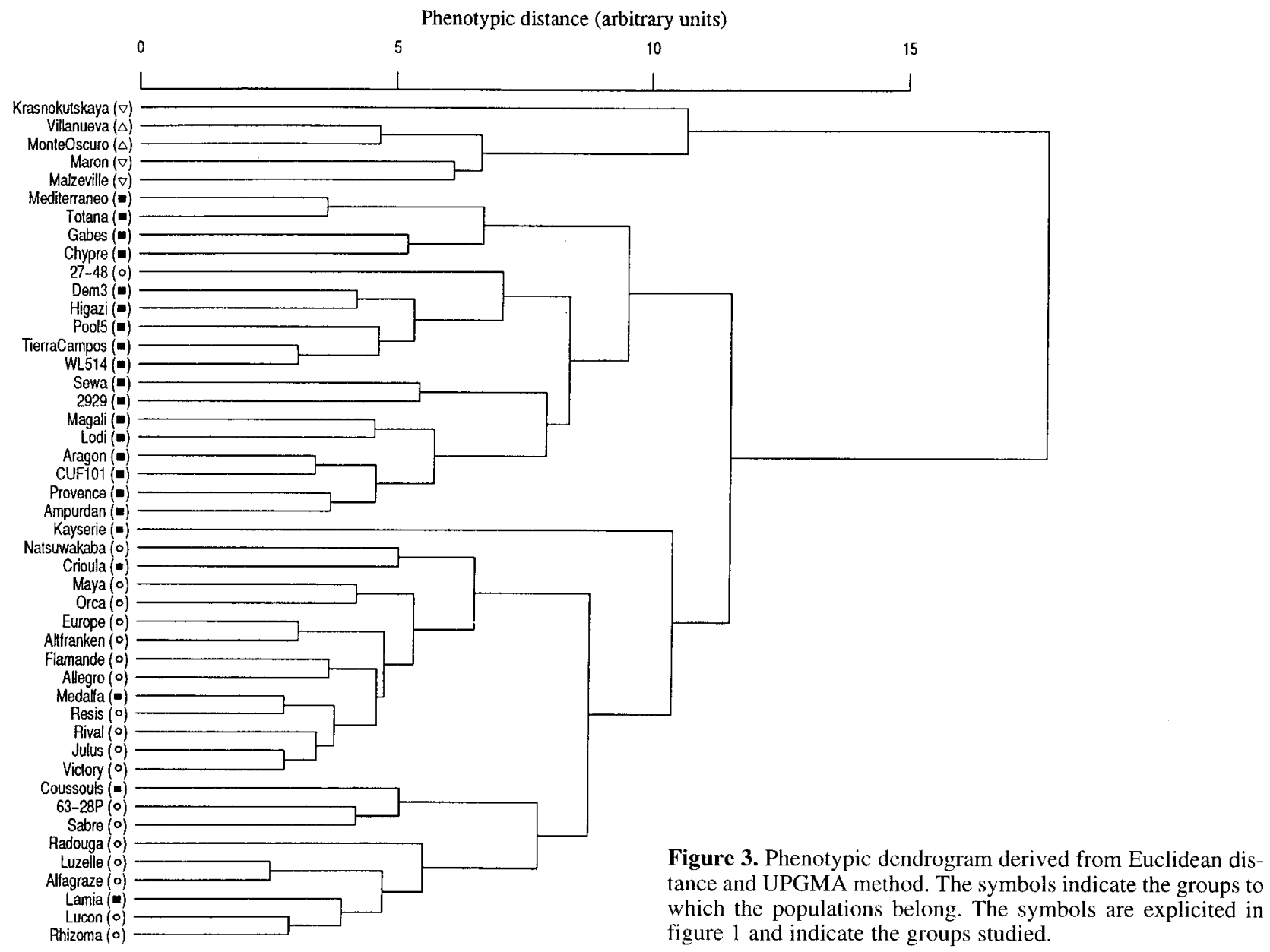

competition due to its neighbours. This experimental design does not provide information on the agronomic potential under a dense canopy where only a small percentage of the stems contributes to the forage yield. The number of individuals in each replication makes possible the calculation of the mean value of the populations. The within-population variation is large in alfalfa cultivars and landraces [6]. On the same set of populations, Crochemore et al. [5] showed that, for the RAPD markers, it was larger than the between-population variation. However, in absence of true replicates of each plant, it was impossible to assess the within-population variation for the morphological characteristics.

The effects of the cycles were important as well as the interaction between cycle and population.
The temperature and daylength play a major role on the growth and on the phenological stages of the lucerne plants, with a differential response according to the genotype $[4,11,14,15]$. The evaluation of the same set of populations in another environment could have given a different structuration of the set of populations. In the present study, a wide range of material was evaluated in a single location, Lusignan, in the west of France. The climatic conditions are well suited for the Flemish types but possibly less favourable to the expression of the agronomic potential of the Mediterranean material, even if none of this material suffered damages and disappeared during the winter. A second site, in a Mediterranean climate would have been beneficial but setting a similar experimental lay-out with the 
Table IV. Percentage of the different patterns of flower colour in the 46 populations.

\begin{tabular}{|c|c|c|c|c|}
\hline Population & Purple & $\begin{array}{l}\text { Varie- } \\
\text { gated } \\
\text { Purple }\end{array}$ & $\begin{array}{l}\text { Varie- } \\
\text { gated } \\
\text { Yellow }\end{array}$ & Yellow \\
\hline Maron & & 6 & 2 & 92 \\
\hline Malzeville & & & & 100 \\
\hline Krasnokutskaya & & 9 & 8 & 83 \\
\hline Villa Nueva & 100 & & & \\
\hline Monte Oscuro & 98 & 2 & & \\
\hline Dem3 & 100 & & & \\
\hline Pool5 & 100 & & & \\
\hline Gabes & 100 & & & \\
\hline Provence & 98 & 2 & & \\
\hline Magali & 84 & 16 & & \\
\hline Medalfa & 85 & 15 & & \\
\hline Lodi & 98 & 2 & & \\
\hline Aragon & 98 & 2 & & \\
\hline Ampurdan & 84 & 16 & & \\
\hline Tierra de Campos & 88 & 12 & & \\
\hline Mediterraneo & 100 & & & \\
\hline Totana & 100 & & & \\
\hline Coussouls & 67 & 33 & & \\
\hline Crioula & 87 & 13 & & \\
\hline WL514 & 97 & 3 & & \\
\hline CUF101 & 100 & & & \\
\hline Sewa & 97 & 3 & & \\
\hline Chypre & 100 & & & \\
\hline Higazi & 100 & & & \\
\hline 2929 & 97 & 3 & & \\
\hline Lamia & 96 & 4 & & \\
\hline Kayserie & 96 & 4 & & \\
\hline Marais de Luçon & 80 & 20 & & \\
\hline Flamande & 79 & 21 & & \\
\hline Natsuwakaba & 100 & & & \\
\hline Europe & 90 & 10 & & \\
\hline Rival & 84 & 16 & & \\
\hline Resis & 80 & 20 & & \\
\hline Maya & 86 & 14 & & \\
\hline Alegro & 97 & 3 & & \\
\hline Orca & 89 & 11 & & \\
\hline $63-28 \mathrm{P}$ & 66 & 34 & & \\
\hline Luzelle & 62 & 38 & & \\
\hline $27-48$ & 99 & 1 & & \\
\hline Julus & 80 & 20 & & \\
\hline Alfagraze & 100 & & & \\
\hline Altfranken-Sm-St & 57 & 42 & & 1 \\
\hline Radouga & 98 & 2 & & \\
\hline Sabre & 43 & 53 & & 4 \\
\hline Victory & 72 & 28 & & \\
\hline Rhizoma & 72 & 27 & & 1 \\
\hline
\end{tabular}

same set of characteristics in another location would have been difficult and time-consuming. Consequently, it can be considered that the present results do not indicate the agronomic potential of the Mediterranean material under a Mediterranean climate. However, this does not mean that the experiment misclassified some of the populations. This would only be the case with a strong population $\times$ environment interaction. Despite the fact that there are no data to support this conclusion, it may be expected that some variations among the Mediterranean material have been poorly described, even if, as shown by figure $2 . B$, this material was well scattered on the PCA diagrams.

The group of wild populations included falcata populations from the east of France (Maron, Malzeville) and from Ukraine (Kratsnokutskaya) and sativa populations (Monte Oscuro, Villa Nueva). This group was characterized by a very slow regrowth after the cuts, no growth during the winter and a late growth in spring. They flowered late at all the cycles. The plants had a prostrate growth habit with a high proportion of rhizomatous plants. They also produced short and light stems and a very low seed yield. The flower colour was the only characteristic to distinguish the sativa wild populations from the falcata ones as already described by several authors $[21,23,31,34]$. The similarities of the morphology between the wild forms of both subspecies is likely to be the result of a convergent adaptation to escape selection pressure due to grazing, where the prostrate growth habit and the rhizomatous root system is favoured [7, 17, 28].

When compared to the wild populations, all the cultivated forms showed an erect growth habit, strong regrowth after the cut and a range of variation for the autumn and the winter growth. They also had on average an earlier flowering at all cycles. The proportion of rhizomatous plants was low or null. The stem lengths, the forage production and the seed production were higher while the leaf to stem ratio tended to be lower at all cycles.

Among the cultivated material, with the morphological characteristics used and under a spaced plant design, there was no clear cut difference between the varieties obtained from a breeding pro- 


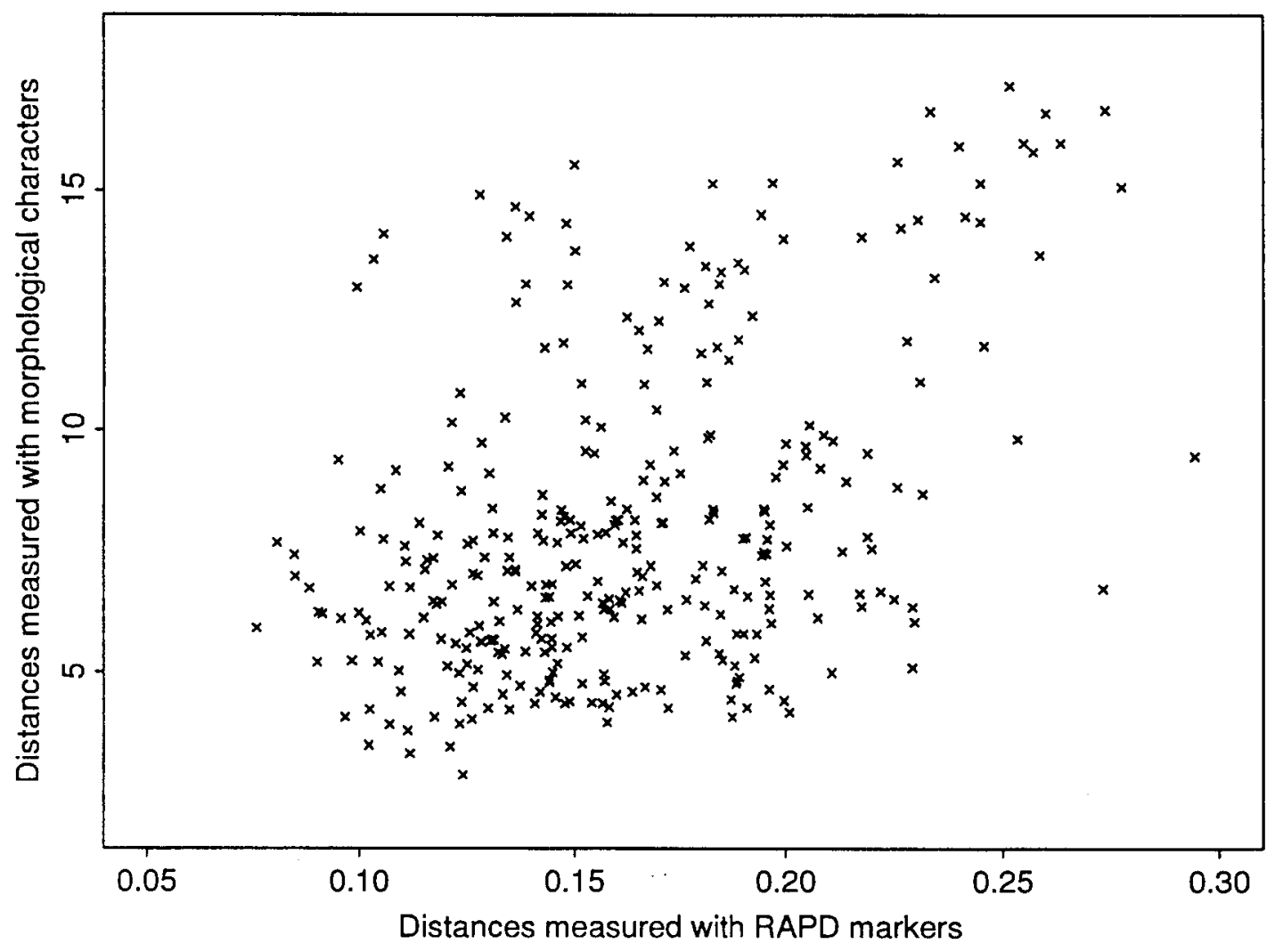

Figure 4. Relationship between the distances calculated on the morphological characteristics and the distances based on the RAPD markers for 26 populations.

gramme from the landraces obtained from a longterm empirical selection. This means that the selection methods do not induce a bottleneck or a shift for the characteristics taken into account in the present study. It would have probably been different if characteristics related to pest and disease resistance had been included in the study. Two major clusters were identified according to their morphology, corresponding to the Mediterranean and the Nordic types, respectively, while a Turkish population showed a mixed behaviour.

The Mediterranean group was characterized by vigorous regrowth after the cut, continuous growth during the winter, late flowering in the summer cycles, high stem weight in summer and mean stem weight in the spring. The later flowering of the
Mediterranean material could be questioned and attributed to a poor adaptation to the climate of Lusignan, cooler than the Mediterranean region. Such a pattern was observed by Rumbaugh et al. [33] when studying Moroccan material in Utah (USA). However, in the present study, the flowering date at cycle 4 was highly correlated with the mean number of stem internodes below the first inflorescence. Among the Mediterranean populations, the variety Magali was the earliest at flowering and the most productive in spring. For these reasons, it appeared with the Nordic types on the first two axes of the PCA. This intermediate position was likely due to its genetic origin, as it was created through a polycross between the landrace Provence and the old variety Du Puits which is introgressed with falcata $[13,20]$. 
Table V. Values of the $\mathrm{Z}$ parameters in the analysis on 26 populations of the relationship between the Euclidean distance and the distance based on the RAPD markers.

\begin{tabular}{lccc}
\hline & Calculated value & Range from simulations & $\mathrm{P}(\mathrm{Z}>\mathrm{Z}$ calculated $)$ \\
\hline $\mathrm{Z}_{\text {total }}$ & 877.7 & $809-894.6$ & 0.0055 \\
$\mathrm{Z}_{\text {Within }}$ & 259.8 & $247.1-265.0$ & 0.104 \\
$\mathrm{Z}_{\text {Between }}$ & 617.9 & $487.6-593.0$ & 0 \\
\hline
\end{tabular}

2000 simulations were performed for each test.

The Nordic group was characterized by a slower regrowth after the cuts, a strong fall dormancy, early flowering and long stems. They had numerous internodes in spring and few in the summer cycles. The population Crioula was the only population without rhizomatous plant clustered in this group. This population had shorter stems in spring than the average of the group and also produced less seeds. According to these characteristics and in agreement with its origin, it was located with the Mediterranean populations on the first two axes of the PCA. Crioula was obtained from populations introduced in Brazil by German and Italian immigrants in the middle of the last century [27] and shows major similarities with the Italian landrace Romagnola (G. Genier, pers. comm.). Its winter growth was in the average of the Mediterranean group.

Lamia (Greek population), Medalfa and Coussouls, two French varieties, despite being bred in the Mediterranean region, were classified with the Nordic group. All three flowered early in both 1995 cycles, as did the Nordic group. Moreover, Medalfa has among its constituents $1 / 8$ of the Flamande population. The growth habit of Coussouls, its fall dormancy and the presence of rhizomatous plants explain its clustering with the Nordic group.

The rapid regrowth after the cut and the winter growth of the Mediterranean types have been documented by many authors $[1,8,21]$. The present study also showed that the Nordic group grew less during the winter but had a vigorous growth in the spring. The slow regrowth after the cut was particularly marked for the populations from central and northern Europe as well as from Canada and the former Soviet Union. This was also shown by Hauptvogel [16].

For most of the characteristics related to the seed production, the wild populations had significantly lower values than the cultivated ones. However, they did not differ for the proportion of hard seeds. This characteristic strongly depends on the climatic factors during and after the seed maturation [2]. It is also genetically influenced. Lute [24] and Watson [36] cited by Fairey and Lefkovitch [10] reported that $M$. falcata and $M$. media had more hard seeds. Delgado-Enguita [7] also found a higher rate of hard seeds in the Mielgas. The proportion of hard seeds found in our study was surprisingly high, the average being $64 \%$. The lowest value was found in Kayserie with $39 \%$. This could be due to the fact that the test was performed only 2 weeks after the harvest. As a consequence of the high values, this characteristic was not discriminant and only contributed to the fourth axis for both PCAs.

Several authors have shown that the geographic origin of the material was sufficient to obtain a reasonable structuration in groups $[1,3,21]$. However, the groups obtained in a classification depend on the material involved in the study. In our analysis, the geographic origin did not fit exactly with the dendrogram obtained, even if the wild, Nordic and Mediterranean groups have been identified. Our dendrogram depends very much on the dormancy of the material which is more related to the climatic conditions than to the geography. It should also be stated that the dormancy of the Mediterranean material may not have been precisely estimated 
because of the location of the trial, in the west of France.

The analysis of the relationships between the distances based on the morphological characteristics and the RADP markers have been performed on 26 populations common to both studies. This analysis separated two levels of variation, i.e. the major groups of variation and the populations within the groups, the significance being tested without prerequisite information on the distribution of the parameters. This study showed that both types of characteristics separated the major groups of variation in a similar manner. In sweet corn inbreds, Gerdes and Tracy [12] found a low relationship between distance matrices based on phenotypic and RFLP markers as shown by the correlation coefficient $(\mathrm{R}=0.167)$ on 45 inbreds while Lerceteau et al. [22] on Theobroma cacao $\mathrm{L}$. found the distance matrices derived from molecular (RAPD and RFLP) and phenotypic data to be correlated ( $R=0.7,60$ genotypes). In our study, a global correlation coefficient would have a value of 0.51 and would only be induced by the presence of the major groups of variation, which is to some extent related to the subspecies structure. RAPDs and morphological characteristics also gave similar information on the relationships between major groups of variation on other species, such as Brassica [9], Musa [18] and Oryza sativa [35].

The analysis of the genetic differentiation among the lucerne populations showed the importance of the diversity available for breeding. The variation available in each group is very large, even amongst the varieties of one given group in a given region, for instance, the Flemish-type varieties registered in France. Considering that an important part of the genetic variation is a within-population variation [5], this pattern of diversity underlines the large possibilities of genetic improvement which are possible through an exploitation of the genetic variability available in each group.

The position of the wild material, both for the morphological characteristics and the molecular markers [5] and the wide variation within the wild populations show that the wild populations of Medicago sativa and falcata represent massive reservoirs of variation for future breeding of this species. Major concern should be given to the collection and the conservation of this material, in Spain for the wild sativa, and in northern, central and eastern Europe as well as northern Asia for ssp. falcata, especially where the modifications of the agronomic practices may endanger the wild plant populations.

Acknowledgement: We thank J. Jousse and A. Gilly for their technical assistance. M.-L. Crochemore was supported by a fellowship of the $\mathrm{CNPq}$ (Conselho Nacional de Desenvolvimento Cientifico E Technologico, Brazil).

\section{REFERENCES}

[1] Barnes D.K., Bingham E.T., Murphy R.P., Hunt D.J., Beard D.F., Skrdla W.H., Teuber L.R., Alfalfa germplasm in the United States. Genetic vulnerability, use, improvement and maintenance, USDA, Technical Bulletin 1571, Washington, DC, USA, 1977, 21 p.

[2] Bass L.N., Gunn C.R., Hestermann O.B., Roos E.E., Seed physiology, seedling performance and seed sprouting, in: Hanson A.A. (Ed.), Alfalfa and Alfalfa Improvement, ASA-CSSA-SSSA Publishers, Agronomy Monograph No 29, Madison, WI, USA, 1988, 961-983.

[3] Birouk A., Dattee Y., Sadiki M., Roumet P., Évaluation agronomique et adaptation de populations marocaines de luzerne (Medicago sativa L.), Agronomie 9 (1989) 363-376.

[4] Christian K.R., Effects of the environment on the growth of alfalfa, Adv. Agronomy 29 (1977) 183-227.

[5] Crochemore M.L., Huyghe C., Kerlan M.C., Durand F., Julier B., Partitioning and distribution of RAPD variation in a set of populations of the Medicago sativa complex, Agronomie 16 (1996) 421-432.

[6] Dehghanshoar M., Hampton J.G., Gardiner S.E., Genetic analysis among and within populations forming ecotypes and cultivars of lucerne, Medicago sativa (Leguminosae) using RAPD fragments, Plant Syst. Evol. $208,107-119$.

[7] Delgado-Enguita I., Estudio de la variabilidad de las mielgas aragonesas en areas de precipitacion anual inferior a $600 \mathrm{~mm}$, Ph.D. thesis, Universidad Politecnica de Madrid, Madrid, 1989.

[8] Demarly Y., Biologie et exploitation de la luzerne, Ann. Amél. Plant. 3 (1957) 247-272. 
[9] Demeke T., Adams R.P., Chibbar R., Potential taxonomic use of Random Amplified Polymorphic DNA (RAPD) - a case study in Brassica, Theor. Appl. Genet. 84 (1992) 990-994.

[10] Fairey D.T., Lefkovitch L.P., Hard-seed content in alfalfa grown in Canada, Can. J. Plant Sci. 71 (1991) $437-444$.

[11] Fick G.W., Holt D.A., Lugg D.G., Environmental physiology and crop growth, in: Hanson A.A. (Ed.), Alfalfa and Alfalfa Improvement, ASACSSA-SSSA Publishers, Agronomy Monograph $\mathrm{N}^{\circ} 29$, Madison, WI, USA, 1988, 163-194.

[12] Gerdes J.T., Tracy W.F., Diversity of historically important sweet corn inbred as estimated by RFLPs, morphology, isozymes and pedigree, Crop. Sci. 34 (1994) 26-33.

[13] GEVES, Bulletin des variétés de plantes fourragères. Première partie: Fourragères pérennes, Fiches descriptives provisoires et caractéristiques agronomiques des variétés inscrites au Catalogue Français en 1993, Guyancourt, France, 1993, 307 p.

[14] Gosse G., Chartier M., Lemaire G., Guy P., Influence des facteurs climatiques sur la production de la luzerne, Fourrages 90 (1982) 113-133.

[15] Guy P., Blondon F., Durand J., Action de la température et de la durée d'éclairement sur la croissance et la floraison de deux types éloignés de luzerne cultivée, Ann. Amél. Plant. 21 (1971) 409-422.

[16] Hauptvogel P., Evaluation and utilisation of alfalfa genetic resources in breeding programs in Slovakia, FAO Technical Series REUR 36 (1994) 177-179

[17] Heinrichs H.H., Creeping alfalfas, $A \mathrm{dv}$. Agronomy 15 (1963) 317-337.

[18] Howell E.C., Newbury H.J., Swennen R.L., Withers L.A., Ford-Lloyd B.V., The use of RAPD for identifying and classifying Musa germplasm, Genome 37 (1994) 328-332.

[19] International Seed Testing Association, International rules for seed testing, Seed Sci. Technol. 4 (1976) 557-743.

[20] Julier B., Traditional seed maintenance and origins of the French lucerne landraces, Euphytica 92 (1996) 353-357.

[21] Julier B., Porcheron A., Ecalle C., Guy P., Genetic variability for morphology, growth and forage yield among perennial diploid and tetraploid lucerne populations (Medicago sativa L.), Agronomie 15 (1995) 295-304.
[22] Lerceteau E., Quiros J., Soria J., Flipo S., Pétiard V., Crouzilat D., Genetic differentiation among Ecuadorian Theobroma cacao $\mathrm{L}$ accessions using DNA and morphological analyses, Euphytica 95 (1997) 77-87.

[23] Lesins K., Lesins I., Genus Medicago (Leguminosae). A taxonomic study, Junk bv Publishers, The Hague, 1979.

[24] Lute A.M., Alfalfa seeds made permeable by heat, Science (Washington, DC) 65 (1928) 166.

[25] Mantel N.A., The detection of disease clustering and a generalized regression approach, Cancer Res. 27 (1967) 209-220.

[26] Michaud R., Lehman W.F., Rumbaugh M.D., World distribution and historical development, in: Hanson A.A. (Ed.), Alfalfa and Alfalfa Improvement, ASA-CSSA-SSSA Publishers, Agronomy Monograph $\mathrm{N}^{\circ}$ 29, Madison, WI, USA, 1988, 25-91.

[27] Paim N.R., Utilizaçao e melhoramento da alfalfa. In: Workshop sobre o potencial forrageiro da alfalfa (Medicago sativa L.) nos tropicos, Juiz de Fora, M.G., 1994, 141-147.

[28] Piano E., Valentini P., Pecetti L., Romani M., Evaluation of a lucerne germplasm collection in relation to traits conferring grazing tolerance, Euphytica 89 (1996) 279-288.

[29] Prosperi J.M., Angevain M., Mansat P., Valorisation of forage genetic resources for selection of adapted cultivars. Examples of wild Mediterranean lucernes, 6th FAO meeting on Mediterranean Pastures and Fodder Crops, Bari, 1990, 95-98.

[30] Prosperi J.M., Guy P., Génier G., Angevain M., Les luzernes ou le genre Medicago, in: Prosperi J.M., Guy P., Balfourier F. (Eds.), Ressources génétiques des plantes fourragères et à gazon, BRG-Inra, Paris, 1995, 131-168.

[31] Quiros C.F., Bauchan G.R., The genus Medicago and the origin of the Medicago sativa complex, in: Hanson A.A. (Ed.), Alfalfa and Alfalfa Improvement, ASA-CSSA-SSSA Publishers, Agronomy Monograph $N^{\circ}$ 29, Madison, WI, USA, 1988, 93-124.

[32] Rohlf F.J., NTSYS-pc numerical taxonomy and multivariate system. Version 1.8, Applied Biostatistics Inc., New York, 1993.

[33] Rumbaugh M.D., Graves WL., Caddel J.L., Mohammad R.M.,. Variability in a collection of alfalfa germplasm from Morocco, Crop Sci. 28 (1988) 605-609.

[34] Villax E.J., La culture des plantes fourragères dans la région méditerranéenne occidentale, Institut national de la recherche agronomique, Rabat, Morocco, 1963. 
[35] Virk P.S., Ford-Lloyd B.V., Jackson M.T., Newbury H.J., Use of RAPD for the study of diversity within plant germplasm collections, Heredity 74 (1995) 170-179.

[36] Watson D.P., Structure of the testa and its relations to germination in the Papilionaceae tribes Trifoliae and Loteae, Ann. Bot. 12 (1948) 385-409.
[37] Yamada T., Suzuki S., Classification of alfalfa cultivars by the clustering method based on quantitative characters: its significance in the introduction and conservation of genetic resources, in: Matsuo T. (Ed.), Gene Conservation, Japanese Com. for the International Biological Program (JIBP), Volume 5, 1975, 137-145. 